811.163.41'367.622'366.2

$811.163 .41 ' 367.622 ' 366.52$

https://doi.org/10.18485/sj.2018.23.1.25

ДИНА П. ТОМИЋ АНИһ

Универзитет у Београду

Филолошки факултет
Оригинални научни рад

Примљен: 04. 01. 2018.

Прихваћен: 29. 01. 2018.

\title{
ДВОРОДНЕ ИМЕНИЦЕ ДОМАЋЕГ ПОРЕКЛА СА ДВОЈАКОМ ДЕКЛИНАЦИЈОМ ${ }^{* *}$
}

У овом раду испитујемо које се двородне именице домаћег порекла обрађене у једнотомном Речнику српскога језика могу означити као именице са двојаком деклинацијом и на основу тога желимо да утврдимо који се од претпостављених типова двојаке деклинације могу срести у српском књижевном језику. Циљ рада је да осветли појаву двојаке деклинације и да покаже да овакав вид двородности није маргинална појава у језику, која се може свести на тек неколико изолованих лексема.

Кључне речи: српски језик, род именица, двородне именице, двојака деклинација, хетероклитике, флективни дублети, морфолошки дублети.

\section{1. УВОД}

Двојака деклинащија подразумева појаву да се једној именичкој основи могу придружити наставци двају деклинационих типова. Конгруенција таквих именица по правилу следи из деклинационог типа и лишена је семантичког

*dina@fil.bg.ac.rs

** Овај рад је настао у оквиру пројекта Српски језик и његови ресурси: теорија, опис $и$ примене (бр. 178006), који у целини финансира Министарство просвете, науке и технолошког развоја Републике Србије. 
критеријума (пошто именице у овом типу двородности, за разлику од оне која подразумева двојаку конгруенцију, по правилу не означавају нешто живо).

Претпостављени типови двојаке деклинације које можемо очекивати су следећи:

(А) двојака деклинација је могућа и у једнини и у множини;

(Б) двојака деклинација је могућа само у једнини;

(B) двојака деклинација је могућа само у множини;

(Г) деклинација у једнини је другачија од оне у множини.

У овом раду ћемо на материјалу из једнотомног Речника српскога језика (PCJ) испитати које се групе именица могу означити као амбидеклинабилне (типови А, Б и В) односно дводеклинационе (тип Г) и који се од претпостављених типова двојаке деклинације могу срести у српском књижевном језику.

За потребе овог истраживања одабрали смо именице које нису страног порекла, јер именице страног порекла које се одликују двојаком деклинацијом, а којих такође има много, отварају нешто другачија питања. Циљ овог рада је, дакле, да осветли појаву двојаке деклинације и да, на основу илустративних примера, покаже да није реч о потпуно маргиналној појави у језику, која се може свести на тек неколико изолованих лексема.

\section{1. Морфолошки дублети}

Двојака деклинација, иако је у српском језику одлика релативно великог броја именица, обично се само узгред помиње у литератури, као нпр. у Савременом српскохрватском језику М. Стевановића (1981: 178-179): „Неке именице које имају двојак облик могу бити двојаког рода. Такве су именице пӧрез (м. р.) и са истим значењем пӧреза (ж. р.), оेснов (м. р.) и о̀снова (ж. р.), бёдра (ж. р.) и бѐдро (c. p.), тети́ва (ж. р.) и тётӣво (с. р.). И у другим случајевима код именица исте основе а различитих завршетака, њихов граматички род се одређује према тим завршецима, тј. према тим облицима и према облицима њихових атрибута".

Речи као што су ове које је навео М. Стевановић могу имати промену по две деклинационе врсте и њих Б. Тафра (2005: 81) назива двородовним именицама и разнородовним именищама у једнини и множини, и одваја их од оних које су именице опћега рода (епищени), а срећу се и термини хетероклитичне или хетерогене именице (Мартиновић 2015: 97). Ова појава се у српској литератури најчешће означава термином морфолошки дублети. „Посебан случај су морфолошки дублети наведени без наставка за генитив, нпр.: га́реж м и ж (РСАНУ) или га́реж ж и м (РМС). Ту се показује двојака промена (односно два граматичка рода), а не граматички и природни род, као код двородних именица III врсте” (Поповић 2000: 72). Другим речима, овим именичким основама могу се придружити наставци двеју деклинационих 
врста, а конгруенцијски индикатор ће бити одређен парадигматским (Ивић 1960: 195; Томић 2011: 212-214). ${ }^{1}$

Уместо што смо рекли „овим именичким основама” могли смо рећи и „овим именицама", али то не би било довољно прецизно, јер се у речничкој одредници „га́реж м и ж”, коју Љ. Поповић помиње, „по традицији” налазе заправо две различите лексеме: „По традицији, физичке се алолексе убрајају међу дублете, алтернативне лексемске форме. Обично се само ортографски дублети сматрају алолексама исте лексеме (нпр. hommage и омаж), док се фoнетски (нпр. ухо и уво), те морфолошки дублети (нпр. архив и архива) сматрају засебним лексемама" (Шипка 1998: 12). Из овог објашњења закључујемо да се морфолошки и фонетски дублети (односно алтернативне лексемске форме) не могу сматрати алолексама, па нам у контексту именица које посматрамо остаје да за сада користимо само термин морфолошки дублети. „У нашој лингвистици уобичајено је да се дублети деле на морфолошке дублете (архив - архива) и фонемске дублете (ухо-уво)" (Драгићевић 2007: 246). Као што видимо, однос између размер и размера, на пример, не може се, према „нашој лингвистици”, означити као однос између двеју алолекса исте лексеме, већ је реч о двема различитим лексемама са потпуно истим семантичким садржајем: ,лексички дублети могу се угрубо дефинисати као различите лексеме истог коријена, а идентичног значења. Однос значења, дакле, формално се представља као и код истозначница: А $\equiv$ В” (Шипка 1998: 47).

Поставља се питање колико је за одређење појма лексеме битан онај њен део који се не тиче корена, а не тиче се ни значења. „Једна врста морфема носи информације о темељном значењу ријечи, друга носи информације о модификовању тог темељног значења, а трећа информације о функцији коју лексема обавља" (Шипка 1998: 16). Ова трећа врста морфема чини разлику између парова речи о којима говоримо. Њих Д. Шипка назива функционалним морфемама и за њих каже: „Функционалне морфеме не учествују у формирању нових лексичких јединица, па им у лексикону и није место" (Шипка 1998: 17). Ако функционалне морфеме не учествују у формирању нових лексема, питање је да ли онда можемо говорити о двема лексемама у случајевима као размер : размера, где алтернирају само функционалне морфеме.

\section{2. Флективни дублети - једна или две лексеме}

Према Згусти, два су могућа тумачења лексеме: „Цијела парадигма, цио низ облика који припадају једној ријечи некад се зове лексема. У другим тер-

${ }^{1}$ Термине конгруениијски индикатор (К-индикатор) и парадигматски индикатор (П-индикатор) користимо према М. Ивић (1960 и 1966). 
минологијама лексема је дио ријечи за који се чини да носи лексичко значење за разлику од граматичког морфема" (Згуста 1991: 115).

У првој дефиницији, лексема је реч са свим облицима који јој припадају. ${ }^{2}$ Ова дефиниција заправо није прецизна јер је термин реч или (а) употребљен у значењу морфосинтаксичка реч, дакле само једна од конкретних реализација лексеме, која онда има свој облик и не могу јој „припадати” други облици; или је (б) употребљен у значењу ,апстракција свих значења и облика” језичке јединице која се обично назива лексемом, у ком случају добијамо неку врсту циркуларне дефиниције типа „лексема је лексема...”.

Друга дефиниција је прецизнија, ако узмемо у обзир то да граматичке морфеме, као функционалне, не могу носити лексичко значење и не могу продуковати нове лексеме. А код променљиве речи је део који носи значење заправо њена граматичка основа. И када би се у првој дефиницији термин реч заменио термином граматичка основа, дефиниција би била прецизнија: „Цијела парадигма, цио низ облика који припадају једној граматичкој основи некад се зове лексема".

Лексема, дакле, обухвата граматичку основу и низ обличких морфема који су тој граматичкој основи додељени као обележја њене класификационе категорије (односно који јој могу бити додељени да би лексема могла имати морфосинтаксичку функцију у својој конкретној реализацији). Овако изведеној дефиницији додали бисмо и то да је лексема још и скуп свих значења која се њеним формалним појавама могу исказати. Под претпоставком да је ова дефиниција лексеме тачна и довољно прецизна, следеће је питање да ли су морфолошки дублети две лексеме (као што се наводи у литератури) или постоје основи да се они тумаче као једна лексема.

Као прво, морфолошки дублети увек имају исту граматичку основу. Друго, обично се претпоставља да се једној граматичкој основи увек придружује један и само један низ обличких морфема (што најчешће и јесте случај - једна именичка основа најчешће има наставке само једне деклинационе врсте у оба своја броја).

Међутим, и ако се једној основи придружи само један низ падежних наставака (један П-индикатор), не значи да се том приликом неће јавити морфолошка дублетност - именица месеи нпр. у генитиву множине може имати наставке или - $a$ или $-u$, чија дистрибуција зависи од семантике именице, а именица поштар може у вокативу једнине имати наставак -е или -y, без икакве везе са семантиком. Код ове врсте морфолошке дублетности никада се о дублетима не говори као о двема лексемама.

\footnotetext{
${ }^{2}$ Додали бисмо - ако „реч” уопште има више облика. Пошто се у овом раду бавимо именицама, а не непроменљивим врстама речи, нећемо се у даљем тексту освртати на то што неке „речи” имају само један облик.
} 
Некада је једној именичкој основи (са једним значењем) чак немогуће прикључити само један низ наставака (деклинациони тип) који би функционисао и у једнини и у множини - именичка основа ок- у једнини има П-индикатор I деклинационе врсте, док у множини своју морфосинтаксичку функцију остварује наставцима IV деклинационе врсте, при чему има значење „органа чула вида", са веома разгранатом полисемичном структуром. Морфолошка дублетност јавља се у множини, када у неким значењима ове лексеме она може имати наставке и по I врсти. Ни код овог типа дублетности обично се не говори о двема лексемама.

У примерима типа размер : размера видимо да се некада једној именичкој основи могу доделити и различити низови наставака, тј. различити П-индикатори, кроз целу парадигму. Одабир П-индикатора не мора бити у вези са семантиком именица (нпр. литар : литра), а онда када јесте (тоалет : тоалета, на пример), чини се да разлике у значењима не излазе из оквира полисемије. Стога можемо рећи да су и овакви парови морфолошких дублета део једне лексеме која обухвата њихову (а) (истоветну) граматичку основу и (б) низове обличких морфема (тј. све обличке морфеме) који тој граматичкој основи могу бити додељени, заједно са (в) скупом свих значења која се овим формалним склоповима могу исказати (при чему полисемична структура може али не мора бити богатија него код сваког дублета појединачно).

Да бисмо омогућили прецизну употребу термина у овом раду, термином морфолошки дублети ${ }^{3}$ назваћемо алтернативно појављивање појединачних обличких наставака (типа мёсёи̧а̄ : месе́ий у ген. мн. лексеме месеи), док ћемо парове типа очи : ока (ном. мн.) или размер : размера назвати флективним дублетима, под чиме подразумевамо појаву да се за једну именичку основу може везати више од једног П-индикатора, при чему се могућност алтернативне парадигме приписује једној лексеми са целокупном њеном значењском структуром, полисемичном или не.

У једном флективном дублету могу постојати два типа значењских односа: истозначност, при којој два дублета имају идентичну целу полисемичну структуру, и блискозначност, при којој значењско преклапање обухвата само део полисемичне структуре, а без обзира на значењске односе између дублета, њихово постојање најчешће почива на различитим сферама употребе.

${ }^{3}$ Можда би се овом термину могла додати и спецификација „у ужем смислу”. 


\section{2. ФЛЕКТИВНИ ДУБЛЕТИ КОД ИМЕНИЦА ДОМАЋЕГ ПОРЕКЛА}

Ако изворног говорника замолимо да наведе једну именицу која у српском језику може имати два рода, вероватно ћемо као одговор добити именицу бол. Она може имати промену по I или по IV деклинационој врсти, а од деклинационе врсте зависи да ли ће бол бити мушког односно женског рода. Овај тип двородности, који почива на двојакој деклинацији (а чије смо носиоце назвали флективним дублетима), уопште није редак међу именицама српског језика, напротив.

Пре свега, овом појавом су обухваћене многе именице женског рода које у номинативу једнине имају као наставак -ø, односно које се у номинативу завршавају на консонант. Такорећи све именице у овој класи су инаниматне, а већина њих има апстрактно значење (Игњатовић 1960: 58). Четврта деклинациона врста је скоро потпуно затворена класа именица у српском језику. Једини донекле продуктиван суфикс који изведеницама додељује П-индикатор ове деклинационе врсте је суфикс -ост.

Затварање класе о којој говоримо очитује се у три манифестна момента: (а) осим поменутог суфикса -ост, ниједан други није продуктиван и број именица домаћег порекла ове врсте не расте; (б) именице страног порекла које се завршавају на консонант могу добити само П-индикатор I деклинационе врсте4 (уп. Игњатовић 1963: 215); (в) именице IV врсте показују тенденцију преласка у I (та мрест $\rightarrow$ тај мрест) или III деклинациону врсту (та сен $\rightarrow$ та сена), аналогијом према номинативном завршетку односно према Киндикатору (та сет $\rightarrow$ тај сет или та сета).

Приликом преласка из једне у другу деклинациону врсту, неко време се у језику једној именичкој основи могу приписати оба парадигматска индикатора и тада говоримо о појави флективних дублета. Онај „изворни” дублет постаје стилски маркиран и архаизацијом му се смањује домен употребе. Пошто је затварање IV деклинационе врсте још увек у току, а приликом преласка у I врсту ове именице мењају и свој род, њих ћемо описати у одељку 2.1. и показати, на грађи из РСJ, појаву двојаке деклинације (типа А) и двородности која је с њом у вези.

Када именица не означава живо биће одређеног пола, њен конгруенцијски индикатор ни на који начин не зависи од семантике, па ни одабир П-индикатора који ће именичка основа добити нема никаквих основа у ванлингвистичким фактима. Тако П-индикатори I и III деклинационе врсте постају конкурентни. ${ }^{5}$

\footnotetext{
${ }^{4}$ Једини изузетак који смо нашли је именица кураж.

${ }^{5} \mathrm{IV}$ деклинациона врста је, као што смо видели, затворена, а то важи и за II деклинациону врсту, чији се број чланова данас увећава такорећи још само деминутивно-хипокористичним суфиксом -че, који се додаје аниматном денотату.
} 
Некада ће превладати један, некада други (у зависности од суфикса, аналогијом према значењу неке друге именице и сл.), а некада ће конкуренција ових Пиндикатора створити пар флективних дублета, који ће се онда разликовати и по роду. Највећи број именица домаћег порекла са флективним дублетима има именичку основу с двојаким П-индикаторима I и III деклинационе врсте, и они ће бити описани у тачки 2.2. Остала поглавља рада доносе мање фреквентне алтернације парадигматских класа.

Највећи број именица са двојаком деклинацијом по I и III деклинационој врсти има инаниматне денотате. Једина међу њима која као денотат има особу јесте вӧђ (а). Ова именица, међутим, с обзиром на то да има семантичку компоненту са значењем мушког пола, са П-индикатором III деклинационе врсте не мења једнински К-индикатор и развија у множини, независно од свог флективног дублета, двојаку конгруенцију, која није тема овог рада.

\section{1. Ж, IV или M, I}

У РСЈ смо нашли следеће примере двородности која одговара типу А, јер се односи и на једнину и на множину ${ }^{6}$ ових именица: блуิд, болл, влаิт, га̂p,

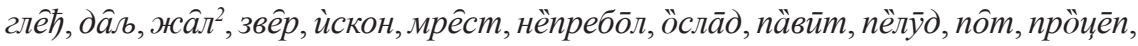

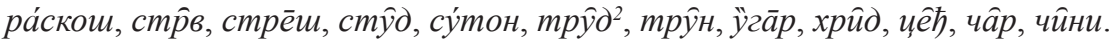

Међу именицама IV врсте са тенденцијом преласка у „мушки род” налази се нешто већа група именица са суфиксом -еж, који је „веома хетероген и неправилан суфикс, како по значењу тако и по граматичким особинама (jep бар половина изведеница осцилира између мушког и женског рода)" (Клајн 2003: 74). Суфикс -еж претежно гради именице са апстрактним значењем, које je у IV деклинационој врсти доминантно. Неке од изведеница овим суфиксом имају збирно значење, које је благо померено из сфере конкретности и код њих се може очекивати постепени прелазак из једне у другу деклинациону врсту: жи́веж, мла́деж, пи́леж, ру́деж, си́тнеж, ста́леж, ста́реж, шйљењ.

Друга група именица са суфиксом -еж означава неку врсту радње или стања, дакле, такође има значење које није конкретно, а има пејоративан призвук: бри́деж, вр́веж, вр́теж, га́деж, га́реж, гња́веж, гњи́леж, гра́беж, да́веж, дре́меж, ква́реж, кр́nеж, ла́веж, ме́теж, мр́твеж, му́теж, му́тнеж, па́леж, пр́деж, свра́беж, свр́беж, тр́nеж, три́леж, ту́леж, цви́леж.7 Доминација

\footnotetext{
${ }^{6}$ Већина ових именица не спада у заједничке, па се као такве оне типично не користе у множини. Претпостављамо, међутим, да би све оне, када би имале облике множине, ове облике могле градити по оба деклинациона типа о којима говоримо.

${ }^{7}$ Таквих има у српском језику више него што их је у РСЈ наведено. У Обратном речнику (Николић 2000), нпр., налазимо и следеће одреднице: гла́деж, гр́меж, гу́стеж, дро́беж, ја́деж, кла́теж, ко́леж, кра́деж, кри́веж, кр́теж, пи́љеж, ру́беж, смр́деж, спа́веж, сра́меж, стр́веж,
} 
употребе квалификатора „м” у РСЈ вероватно је последица јаче гравитације ове семантичке групе ка I деклинационом типу.

Конкретно значење, које налазимо код неколико именица са суфиксом -еж, требало би да онемогући приписивање П-индикатора IV врсте добијеној именици, с обзиром на то да једном затворена класа не трпи семантичке иновације. Именице бо́деж, да́веж, кра́теж, лу́пеж, мӓдеж, млӓдеж, па́деж, ри́беж и црттеж све имају квалификатор „м” у РСЈ.

Све именице са суфиксом -еж које имају конкретно значење, дакле, имају П-индикатор I деклинационе врсте. Овакав индикатор имају и многе именице са апстрактним значењем, за које је IV деклинациона врста још увек отворена. Судећи по обради у РСJ, једино се код именица збирног значења са суфиксом -еж може говорити о једнако фреквентној употреби обају дублета, оног са мушким и оног са женским родом (уп. Цвијовић 2017). Овде изнете „закључке” треба узети само као хипотетичке и преиспитати их на корпусу који би био репрезентативан за савремени српски књижевни језик.

\section{2. М, I или Ж, III}

Као што смо већ напоменули, највећи број именица домаћег порекла са флективним дублетима има именичку основу с П-индикатором алтернативних вредности I и III деклинационе врсте и познаје двородност типа А.

Када су значења двају флективних дублета у потпуности идентична, њихов значењски однос одговара оном код лексема-истозначница, односно код апсолутних синонима. У том случају се флективни дублети углавном наводе у РСЈ под истом одредницом.

Употреба везника „и” у квалификацији рода означава да су обе вредности П-индикатора именичке основе једнако прихватљиве у књижевном језику, што видимо у примерима: бѐлег и бѐлега, за́лог и за́лога, за́сен и заิсена, за́ток и за́тока, по̀тплат и пӧтплата, при́ток и прӥтока, приิд и при́да, прӧте̄г и прӧтега, ра́зблуд и раิзблуда, ра́змер и ра́змера, стр̀ник и стр̀ника, и код неколико ономатопејски мотивисаних парова: блеิк и блёка, зуิк и зйка, псиิк и псӥка, хррсак и хйска.

Употреба заграде означава да је један дублет уобичајенији или прихватљивији са становишта језичке норме од оног који је дат у загради: за̂прега (за́прег), за́струг (заิструга), зо́ља (зӧљ), по̀рез (пӧреза), прёљуба (пре́љуб), свињо̀кољ (свињо̀коља). ${ }^{8}$

иявр́чеж, ча́меж. Питање је, међутим, колико су све ове лексеме као група, укључујући и оне са апстрактним значењем из РСЈ, данас фреквентне у српском језику.

${ }^{8}$ Овде би се вероватно могли наћи и флективни дублети појав : nojaва и nocem : nocema, које су у Једнотомнику забележене само као именице III деклинационе врсте. 
Однос истозначности међу флективним дублетима, међутим, понекад није назначен смештањем обеју дублетних форми у један речнички чланак, већ се једна од одредница даје са дефиницијама значења, а друга се упућује

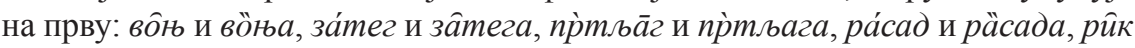
и рйка, рузг и ру́zа, уेклад и йклада.

Другачији је случај када се значењски однос флективних дублета може означити као блискозначност. Тада у РСЈ налазимо две одреднице и два речничка чланка као последицу разликовања фонетског састава лематског облика двају дублета, а свакој од одредница биће прикључено подзначење које је везано за конкретан члан дублетског пара. Заједничка значења биће наведена под једном од две одреднице, док ће се друга на њих само упућивати: буботак м : буботка ж, бук м : бука ж, вареник м : вареника ж, вез² м : веза ж, врисак м : вриска ж, врика ж : вршак м, гак м : гака ж, грак м : грака ж, драч м : драча ж, жар м : жара ж, забран м : забрана ж, запон м : запона ж, запонак м : запонка ж, звек м : звека ж, зврк м : зврка ж, зрак м : зрака ж, јар м : јара ж, јек м : јека ж, кер м : кера ж, клик м : клика ж, крик м : крика ж, лог м : лога ж, наплав м : наплава ж, натикач м : натикача ж, основ м : основа ж, писка ж : писак м, покор м : покора ж, препек м : препека ж, проред м : прореда ж, пуж м : пужа ж, раскид м : раскида ж, репуш м : репуша ж, скик м : скика ж, судопер м : судопера ж, трк м : трка ж, упут м : упута ж, уток м : утока ж, цврк м : цврка ж, цикк м : цика ж, чам м: чама ж, чуп м : чупа ж, шаш м : шаша ж.

Све овде речено односи се и на флективне дублете ономатопејског порекла, који су прилично бројни. Неколицина њих, као што смо видели, обрађена је у РСЈ као истозначни дублети. За већину би се, према обради у РСЈ, могло закључити да њихови значењски односи одговарају онима код „блискозначница". Ево како је већина именица о којима говоримо обрађена:

\section{3. М, I или C, I}

Према грађи из РСЈ, две именичке основе могу имати двојаку парадигму по „мушком” или „средњем” обрасцу промене I деклинационе врсте: бела́нащ : бела́ние и вйтао : вйтло, оба са потпуним поклапањем значења.

Овамо спада и множина именице посао, код које је амбидеклинабилност ограничена на множинске облике, и то само „у неким конструкцијама”, као што су бапска посла, Ђавоља посла, гледати своја посла, нису ту чиста посла. Ово је, дакле, двородност типа В, која у прегледаном издању РСЈ није регистрована, али у следећем јесте (РСJ 22011: s. v. nòcao). 


\section{4. Ж, III или C, I}

Код свих флективних дублета са моделом двородности „Ж, III или C, I” наилазимо на појаву истозначности: јӓсле (мн.) и јӓсла (мн.), ко̀пита и ко̀nиmо, nера́ja и пера́je, ра́змеђа и ра́змеђе. Према речничкој обради, од других се издваја именица мёсојеђе, која има само множинске облике када припада III деклинационој врсти, а само једнинске облике када се мења по обрасцу промене за средњи род I врсте.

Овај тип двородности означићемо поново као тип А - двојака деклинација могућа је и у једнини и у множини, иако су неке од ових именица pluralia tantum. Без обзира на то што се код ових именица облици једнине не користе, на основу њиховог П-индикатора можемо да их претпоставимо, а свакако немамо основа да претпоставимо само један од ова два парадигматска индикатора (или неки трећи) у једнини.

\section{5. С, I и/или Ж, IV}

И две од три именице са типом двородности А и моделом двојаке конгруенције „C, I или Ж, IV” имају само облике множине: плѐћа и плёћи, $n \ddot{p} c a$ и $п \ddot{p} c u$, добба и добб. Код обрађених именичких дублета који су pluralia tantum видимо однос истозначности, са препорученом употребом облика по I деклинационој врсти и К-индикатором средњег рода. Чланови трећег пара флективних дублета стоје у односу блискозначности, при чему форма доба, са П-индикатором I врсте и конгруентним индикатором средњег рода, има нешто шире значење.

Другачији тип двојаке деклинације налазимо код лексема око и ухо (у њиховим примарним значењима). Оне имају тип двородности Г, код кога није реч о дублетности, већ о деклинационом суплетивизму једнинске и множинске парадигме, при чему се граматичка основа не мења. У РСЈ налазимо следеће одреднице: ӧко с (мн. ӧчи ж, ретко оेка с) [...]; ӧчи ж мн. од око; ӱво, ӱва (ӱвета) (мн. ӱши (увѐта), ген. у̀шијӯ (уве́та̄)) и ӱхо, ӱха (мн. ӱши, ген. у̀шијӯ) [...]; у̀ххо с (мн. ӱши ж, ген. у̀шијӯ) в. уво.

Треба напоменути да код именице око у множини нема двојаке деклинације (амбидеклинабилности), већ да свако подзначење има један и само један могући П-индикатор у множини, ${ }^{9}$ па се овај тип двородности не може сматрати типом В, оног са двојаком деклинацијом у множини.

${ }^{9}$ „Именице ӧко, ӱхо склањају се у синг. као село, а плурал као село има само око, и то кад се говори у пренесеном значењу” (Маретић 1963: 164). И РСЈ напомиње да је „ретко мн. о̀ка с, ген. о́ка̄, обично као отвор на мрежи или окце на кромпиру” (РСJ: s. v. о̀ко). 
Именичка основа ув- може имати двојаки П-индикатор (I или II деклинационе врсте), при чему се К-индикатор не мења, па не можемо говорити о двородности. Њен парадигматски модел могао би се представити као „Јд. С, I и II - Мн. C, I и II”, при чему као множински облици функционишу и они од $y x-$.

Именичка основа $y x$ - има суплетивни множински П-индикатор (без амбидеклинабилности). Парадигматски модел је „Јд. С, I - Мн. Ж, IV”.

\section{6. С, II и Ж, IV}

Посве је специфично питање деклинације (и с њим у вези рода) именице вече(p). Према Маретићу, „именица вёче изгубила је нејасним начином на крају $p$; у синг. је тај облик и мушкога и средњег рода [...]; у плур. је та именица женског рода и склања се као ствар [...], али и у синг. може да буде женског рода" (Маретић 1963: 147).

Стевановић наводи само да ова именица чешће у једнини има облик вече, али не улази у то којој промени тада припада и у којим падежима се користи у том облику: „Именица вечер (која је иначе неупоредиво чешћа у облику вече) у овоме облику је женског рода и онда, природно, има и промену осталих именица IV врсте. У множини она има облике једино по овој врсти" (Стевановић 1981: 244). Множинске облике по II деклинационој врсти налазимо у Граматищи српског језика за гимназије и средње школе, по којој се именица вече одликује ,jеднинском променом: G. вечера - D. вечеру - I. вечером - L. вечеру, а множинском N.-A. вечера, G. вечера̄, D.-I.-L. вечерима" (Станојчић-Поповић 2008: 86).

Двојака деклинација постоји заправо само у једнини, с тим што двојакост деклинације познаје само облик вокатива. К-индикатор пратиће у сваком од облика парадигматски. Означићемо стога овај тип двородности као Б, с напоменом да се амбидеклинабилност огледа само у облику вокатива једнине. Можемо констатовати да би ову лексему са веома специфичним П-индикатором било добро обрадити тако да квалификатор за род јасно представи који се облици када употребљавају (уп. Тафра 2005: 98).

\section{7. М, I или С, I (или Ж, III)}

Речник српскога језика бележи да именичка основа пазух- може имати три конгруенцијска индикатора - мушког, средњег и (ређе) женског рода: näзух и пӓзухо (пӓзуха). Тројак род је код ове именице последица тројаког 
П-индикатора ${ }^{10}$ додељеног њеној основи, чији је модел „М, I или С, I (или Ж, III)”. Тип двородности је А, онај код ког двојака деклинација ${ }^{11}$ обухвата и једнину и множину.

\section{8. М, I или Ж, III или Ж, IV}

Именице чије су граматичке основе наочал- и наочар- према РСЈ могу имати двојак К-индикатор: нӓоча̄ле ж мн. и нӓоча̄ли м и ж мн.; нӓоча̄pe ж мн. и нӓоча̄pu м и ж мн. Двама К-индикаторима сваке од ових именица одговарају три парадигматска: мушког рода ће бити именица када се њеној граматичкој основи додели П-индикатор I деклинационе врсте, а ако је вредност П-индикатора III или IV врсте, именица ће бити женског рода.

Ако на основу конкретних П-индикатора претпоставимо системске облике једнине (који се код ових именица не користе), закључићемо да је њихов тип двородности А.

То важи и за примере сён ж (м) и сёна ж, а и за пример се̂m м (ж), који у другом значењу упућује на сёта ж.

\section{9. М, I или C, I или Ж, III или Ж, IV}

Само једна именичка основа према РСЈ може имати три конгруенцијска индикатора и чак четири парадигматска - то је именичка основа безд(a)н-.

Табела 1. Безд(а)н- $y$ PCJ

\begin{tabular}{|c|c|}
\hline $\begin{array}{c}\text { бѐздан }{ }^{1}, \text {-а и -дна м и бёзда̄н м и ж } \\
\text { бёздна ж и бёздно с }\end{array}$ & $\begin{array}{c}1-2 . \\
\text { в. бездан }\end{array}$ \\
\hline
\end{tabular}

Овој именичкој основи могу бити додељени П-индикатори двају подтипова I деклинационе врсте, када је именица мушког или средњег рода, већ према подтипу, или јој се могу приписати П-индикатори III односно IV врсте, у ком је случају именица женског рода. Цео овај комплексни парадигматски модел, „M, I или C, I или Ж, III или Ж, IV”, представља и даље тип двородности А.

${ }^{10}$ Јер П-индикатор I деклинационе врсте мора садржати и спецификацију „подврсте” промене: (а) мушки род, аниматно; (б) мушки род, инаниматно; или (в) средњи род.

${ }^{11}$ Избећи ћемо коришћење термина тројака деклинација, трородне именище, вишеродне именице и сл., иако би они, разуме се, били прецизнији када говоримо о именицама наведеним у поглављима 2.7-2.9. 


\section{3. ЗАКЉУЧАК}

Следећи примери именичких граматичких основа су репрезентативни за претпостављене типове двородности која се заснива на двојакој деклинацији:

(А) двојака деклинација је могућа и у једнини и у множини: бол-, ситнеж-, порез-, основ-, копит-, беланц-, пазух-, сен- , безд(а)н-; вођ-;

(Б) двојака деклинација је могућа само у једнини: веч(ер)-;

(В) двојака деклинација је могућа само у множини: посл-;

(Г) деклинација у једнини је другачија од оне у множини: ок-/oч-; $y x-/ y u-$.

Двојака деклинација се у српском језику може јавити у сва четири своја типа. Све именице домаћег порекла са овим типом двородности су инаниматне, са изузетком именице вођ $(a)$.

Тип А је најраспрострањенији тип двородности у српском језику који није под утицајем семантике именице или лексичког позајмљивања из других језика. Место у језичком систему флективним дублетима са овим типом двородности најчешће почива на диференцијацији њихових (под)значења, на територијалној или стилској маркираности, тј. на посебној употребној сфери неке од њих.

Тип Б се јавља само код именице вече и то само у облику вокатива једнине, док су у осталим облицима једнине вредности П-индикатора суплетивне, а не двојаке. Због тога можемо констатовати да је овај тип изузетно слаб. Ова констатација важи и за тип В, који се јавља само код именице посао, и то само у множини и само у изразима. Стабилност типа Г одржава фреквентност именица које су овим типом обележене и њихово место у лексичком систему. Пошто именице око и ухо припадају основном лексичком фонду српског језика и често се користе, не изненађује појава суплетивизма у њиховој промени, посебно када узмемо у обзир чињеницу да је однос једнине и множине код именица ионако неретко обележен суплетивизмом.

Овим радом покушали смо да, осим утврђивања типова двојаке деклинације у српском језику, скренемо пажњу на чињеницу да двородни флективни дублети нису реткост међу именицама домаћег порекла, а када се њима додају и именице страног порекла, које ће бити предмет другог истраживања, јасно је да је реч о прилично заступљеној појави и да се род именица не може свести на вредности „мушки”, „женски” и „средњи”, већ се често мора представити сложенијим моделима. 


\section{ЛИТЕРАТУРА}

Драгићевић 2007: Р. Драгићевић, Лексикологија српског језика, Београд: Завод за уџбенике.

Згуста 1991: L. Zgusta, Priručnik leksikografije, Sarajevo: Svjetlost - Zavod za udžbenike i nastavna sredstva.

Ивић 1960: М. Ивић, Обележавање именичког рода у српскохрватском књижевном језику, Београд: Наш језик, Х, 192-211.

Ивић 1966: M. Ivić, Tipovi imeničkog roda u srpskohrvatskom književnom jeziku, Novi Sad: Zbornik Matice srpske za filologiju i lingvistiku, IX, 41-47.

Игњатовић 1960: Д. Игњатовић, О роду именице бол, Београд: Наш језик, $\mathrm{X}, 55-59$.

Игњатовић 1963: Д. Игњатовић, Новине у морфологији унесене најновијим именицама страног порекла, Београд: Наш језик, XIII, 208-224.

Клајн 2003: И. Клајн, Творба речи у савременом српском језику (Други део: Суфиксаиија и конверзија), Београд: Завод за уџбенике и наставна средства - Матица српска - Институт за српски језик САНУ.

Маретић ${ }^{3} 1963$ : T. Maretić, Gramatika hrvatskoga ili srpskoga književnog jezika, Zagreb: Matica hrvatska.

Мартиновић 2015: B. Martinović, Od jezičnoga „pomuškarčivanja” do jezičnoga „poženčivanja”, Pula: Tabula: časopis Filozofskog fakulteta u Puli, 13/1, 91-110.

Николић 2000: М. Николић, Обратни речник српскога језика, Београд: Матица српска - Институт за српски језик САНУ - Палчић.

Поповић 2000: Љ. Поповић, Бивалентни контролори конгруенције: проблем лексикографског описа конкуренције граматичког и семантичког слагања, Београд: Научни састанак слависта у Вукове дане, 29/1, 65-80.

PCJ: Речник српскога језика, Нови Сад: Матица српска, 2007.

PCJ 2011: Речник српскога језика, Нови Сад: Матица српска, 2011.

Станојчић-Поповић ${ }^{11}$ 2008: Ж. Станојчић, Љ. Поповић, Граматика српског језика за гимназије и средње школе, Београд: Завод за уџбенике и наставна средства. 
Стевановић ${ }^{4}$ 1981: М. Стевановић, Савремени српскохрватски језик I, Београд: Научна књига.

Taфpa 2005: B. Tafra, Od riječi do rječnika, Zagreb: Školska knjiga.

Томић 2011: Д. Томић, О категорији рода код именица, Београд: Научни састанак слависта у Вукове дане, 40/3, 209-221.

Цвијовић 2017: Д. Цвијовић, О двородној природи појединих збирних именица на -еж у српском језику, Београд: Српски језик, XXII, 457-469.

Шипка 1998: D. Šipka, Osnovi leksikologije i srodnih disciplina, Novi Sad: Matica srpska.

\section{TWO-GENDER NOUNS OF SERBIAN ORIGIN WITH DOUBLE DECLENSION}

\section{Summary}

This paper investigates which two-gender nouns of domestic Serbian origin listed in Rečnik srpskoga jezika (Serbian Language Dictionary) could be identified as double-declension nouns. The results are used in our effort to specify which double-declension types are commonly found in contemporary Serbian language. The aim of this paper is to shed some more light on the double-declension phenomenon in Serbian so as to prove that this, by no means, can be considered a marginal linguistic phenomenon as the property of very few odd lexemes.

Key words: Serbian language, noun gender, two-gender nouns, double declension, heteroclitics, inflectional doublets, morphological doublets.

Dina P. Tomić Anić 